\title{
Identities in a Culture of Circulation: Performing Selves in Filipina Migration
}

\author{
Deirdre McKay \\ Research Fellow \\ Department of Human Geography \\ Research School of Pacific and Asian studies \\ The Australian National University \\ Canberra ACT 0200 Australia \\ deirdre.mckay@anu.edu.au
}

Introduction: Migration and Philippine Identities

Migration has arguably been the definitive feature of Philippine experiences of globalization. Beginning with the adoption of a Labor Export Policy by the 
government during the 1970s, by the end of the twentieth century the nation had the largest flows of migrant workers in the global economy (Tyner and Donaldson, 1999, p. 1) and the largest per capita number of female contract workers overseas (Boyle, 2002; Mills, 2003). This export of female workers on a temporary basis exemplifies a historic trend for labor markets across Southeast Asia. While rural women have moved to relatively nearby urban centers for work since the colonial era (mid 1800s - 1930s), the global economic restructurings of the 1970s saw this practice extended across national borders. Throughout the region, significant numbers began to move between countries on short-term contracts, taking advantage of the relatively higher returns for labor offered by uneven development (Hugo, 2002). Women from the poorer nations, particularly the Philippines and Indonesia, went to Singapore, Hong Kong, and urban Malaysia. Female migrants from the Philippines used these Southeast Asian cities as entry points for global labor markets, with many moving on to work as domestics in Europe, Israel and North America. By the late 1990s, domestic worker migrants from the rural Philippines had spread around the globe. These migrants created complex long-distance household networks in which they remitted their foreign-currency earnings home to support local livelihoods, shoring up the failing Philippine economy. 
Sending and receiving governments and sending households alike tend to see contract migrants as short-term sojourners. However, many return home only briefly before leaving for a subsequent contract. Without citizenship status in their host nations, it appears inevitable that these migrants will have to return home for good, if only in retirement. However, for most contract migrants from rural areas, local economies do not offer the possibility of a permanent return. The International Labor Organization estimates cash remittances from migrants and emigrants to be equivalent to the annual interest payable on the nation's substantial foreign debt (Rodriguez, 1998; Puri and Ritzema, 1999); individual workers send much of this money home to provide the daily needs of household members. In Manila, approximately 11 per cent of households receive their main source of income from overseas (Tyner and Donaldson, 1999, p. 220). In rural areas, where there is no manufacturing sector, service sector, or significant government employment, the percentage of households dependent on migrant remittances is likely much higher. For instance, in a Northern Luzon village surveyed in the early 1990s, thirteen percent of the adult working population was overseas. Seventy percent of those migrants were female, and sixty-two percent of households reported migrant workers (Pertierra 1994, p. 67). In 2003, I visited a village with approximately 300 households; local NGOs estimated that 85 per cent of these households depended on a female member working as a domestic helper in Hong Kong as their principal wage-earner, a situation 
unlikely to change in the immediate future. ${ }^{1}$ Here, migrant daughters and granddaughters support the first generation of contract domestic workers in their retirement.

Who are these women? According to data gathered before workers depart the Philippines, female migrants are typically single, comparatively well-educated and in their early twenties at the time of their first overseas contract. ${ }^{2}$ Over their life course, large cohorts of migrants will spend most of their reproductive years and mid-life working on contract away from their communities and households. Women and their household members usually identify remuneration as the definitive aspect of the migration experience. Research reports migrants remit a maximum of 75 per cent to a more common $30-50$ per cent ${ }^{3}$ of salaries that currently range between 200 and 500 US dollars per month, with most households receiving about 150 US dollars per month. Beyond reports of earnings remitted, research with Filipina migrants overseas has shown that they often face exploitation and alienation in receiving nations. ${ }^{4}$ In the Philippines, studies of left-behind household members document the reconfiguration of household and community relations in the absence of wives and mothers and attempts to manage flows of remittances. ${ }^{5}$ On their return, many migrants find it difficult to take up their former lives. ${ }^{6}$ Working between migrants overseas and households at home, my current projects explore how the values - both cash and 
symbolic - generated by migration are invested and managed and how migrant identities shift over time. By mapping the dynamic interplay between identities, economy, and cultural fields in what is a highly gendered form of transnationalism, I hope to explain who it is that these migrants and communities are becoming.

Here, I theorize Filipina migration as a 'culture of circulation' (Lee and LiPuma, 2002), extending Lee and LiPuma's (2002) conception of circulation as more than simply the movement of people, ideas and commodities from one culture to another. Circulation is, instead, is a cultural process with its own forms, produced by processes of imagining, recognition, and interaction that work to mediate between notions of tradition and modernity with forms of value. Lee and LiPuma (2002) identify the elements of a culture of circulation as (i) practices of evaluation - or the assessment of authenticity; (ii) constraint limiting of action or interpretation; (iii) consociality - the formation and maintenance of social ties; and (iv) resubjectivation - the production of new subject positions. In this essay, after examining narratives collected from overseas workers and sending communities, I locate each of these elements in interactions between circulating migrants, broader Philippine society, and receiving nations overseas. Migration puts value into circulation - in the form of cash sent home - through the appropriation and redistribution of the surplus labor 
produced by women's work elsewhere. My analysis, however, reveals money is not the only form of value produced and moved through these transnational circuits; forms of cultural and social capital generated by migration are equally important to the 'culture of circulation.'

\section{Circulation and Identities in Women's Work Abroad}

The resubjectivations that create distinctively migrant identities for Filipinas provide a useful starting point for theorizing the circulation arising with longterm, long-distance and place-based flows of female migrants. A partial list of identities attached to migrant women might $\operatorname{read}^{7}-$ Filipina; dutiful daughter; self-sacrificing mother; global servant; domestic helper; nanny; deskilled professional; bagong bayani (national hero); unruly migrant; mail-order bride; 'single' (separated) woman; community stalwart; consumer; stingy returnee; political activist; japayuki (entertainer or sex worker in Japan); entrepreneur; probynsyana (naïve provincial girl); balikbayan (returnee); 'DH' (domestic helper). ${ }^{8}$

Of course, many individual migrants would also identify themselves as other kinds of subjects - perhaps professionals such as doctors, lawyers, nurses; or athletes; or lesbians; or farmers - but these subject positions go unrecognized among the identities available for migrants. Each of the identities listed above is applied to migrants from a different perspective, reflecting variously the subject 
positions of a foreign host or employer, a Philippine nationalist, a classconscious Filipino elite, a co-villager, the members of a migrant's own family and, perhaps, even a migrant herself. Reading the identity-names as subject positions on offer for - or applied to - migrants spreads resubjectivations across different scales. Each subject position depends on processes of evaluation, constraint, consociality that are iterated in interactions between female migrants and others living in sending localities, broader Philippine society and receiving nations and neighborhoods overseas. The transnational economic organization of earning, remittance, and redistribution of value generated by women's work abroad produces and circulates these subject positions. For migrants, these identities are forms of subjectivation that fit individuals, however awkwardly, into the specific subject positions named. Migrants become dependent on these identities - discourses that they have not chosen - to initiate and sustain their agency in transnational cultural fields. Thus, this limited set of subject positions is the frame in which people, including migrants, comprehend and interpret migrants' experiences.

As modes of subjectivation, these identities partly constitute the tensions and entanglements of transnational households and sending localities and the conditions of employment and consociality in receiving nations. To see how these operate, we need to examine the processes of imagination and recognition 
attached to each identity name. My analysis highlights two forms of identity 'Filipina' and balikbayan (returnee). Both identities are ideals for which real women often fall short yet I found - in interviews with female migrants overseas, community members, and returnees in the Philippines - that these identities functioned as definitive explanations for migrant women's feelings or actions and thus served as accounts of their subjectivities. Each identity marks migration-specific practices of evaluation, constraint, and consociality and both are performatives - naming practices that enable and constrain individual agency, simultaneously making selfhood possible.

\section{Philippine Sending Communities and 'Filipina' Identity}

Impressive houses built with migrant earnings characterize Philippine migrant sending areas. Within the sending household, a substantial amount of time and resources is devoted to leisure (Rodriguez, 1998). Many households become oriented to 'abroad' with other family members planning their own migration. Stories circulate through sending villages and kin networks of the lucky few who have parlayed a temporary work contract into 'permanent' status, usually by marrying a host national or gaining a permanent residence visa. Oft-cited examples of 'success' are Hong Kong or Singapore domestic worker migrants who subsequently relocate their households to Canada, Australia, and Britain. ${ }^{9}$ Emigrant households have high prestige in Philippine communities - evidence of 
a new transnational economy of status. Sending community respondents expressed hope that the successive domestic work contracts of their sisters, wives, and daughters would enable their entire family to join their neighbors abroad. Those waiting to migrate depended on remitted monies for their daily needs and stayed in constant contact, usually via cell phone, with relatives overseas. If we unpack the patterns of kinship, indebtedness, distribution of remittances and the communication strategies linking migrants to these households, it becomes clear that dependency on remittances apparently intensifies relations between temporary migrants and their extended-kin at home.

Women's migration restructures household economies as much as it does women's life histories. Many migrants marry between contracts, and bear children on their 'years off', returning to overseas work as soon as practicable. Husbands and extended families take on the work of absent wives and daughters. This work creates new roles, relations, and skills for men who share the parenting of children with a long-distance partner/breadwinner, rather than a 'traditional' wife. Where women leave men and children behind, mothers-inlaw frequently join the household as an economic manager while men tend take up traditionally female tasks such as childcare and laundry as 'solo fathers'. Migrants and their partners must renegotiate their norms for interaction and expectations of each other around remittances, investments, parenting, and 
affection. Many women use migration to initiate such renegotiations in their household. Women are frequently more strongly motivated to migrate by issues of money and respect in the household than by their status in the community (Westwood and Phizacklea, 2000). By enabling a woman to transfer value - in the forms of cash, social and cultural capital - home from 'abroad', a woman's absence can transform gender roles and household expectations.

Migration enhances women's prestige in their communities. Even where women educated in the professions - as nurses, teachers, accountants - take on domestic work overseas, communities do not see this less skilled work as demeaning. The 'debts of gratitude' (utang na loob) and influence generated by workers' transfers to kin are understood by Filipinos to more than make up for the 'low' nature of work abroad (Aguilar, 1999, p. 125) and these debts accrue to each migrant as social and cultural capital on return home. Some returnees I met were able to parlay experiences of overseas domestic work into political influence, running for traditionally male positions in local government.

One of the most satisfying social possibilities opened up through migration is enacting 'Filipina' identity. Being truly 'Filipina' is not actualizable for many women in rural villages, particularly in the indigenous communities where I have conducted most of my research. While the national femininity is 
constructed by the media and popular culture as available to all women in the nation, in reality, 'Filipina' is strongly associated with class and ethnic norms. The term itself is Spanish, and the word Filipina originally signified a female Spaniard born in the Philippine colony. It was not until the rise of nineteenth century Philippine nationalism that colonized women, previously called 'indias', were actually identified as Filipinas. This identification marked the incorporation of colonized women within a European version of upper class female domesticity. Traditional Filipina virtues include women's self-sacrificing maternal care, tolerance of male infidelity and embodiment of pale-skinned mestiza (mixed race) beauty. Accommodating oneself to this Filipina femininity is attractive not least because its accoutrements - light skin, formal education, and conspicuous consumption - are cultural capital and have been since the Spanish era. In rural areas in the Philippines, Filipina identity is associated with being maybahay, lang - expressed in English as 'plain housewife' - meaning a woman who does not perform manual, agricultural labor but simply cares for her home and family. Of course, this 'true Filipina' homemaker status is difficult to perform in localities where men have little access to regular salaried work and subsistence agricultural production is necessary to make ends meet.

Identities shift with economic histories; 'Filipina' is no exception. The late twentieth century global economic restructurings saw 'Filipina' reidentified 
through labor migration. While the term continued to signify housewife and mother in the country, labor export attached 'Filipina' identity firmly to migrant workers who came predominantly from the lower middle classes. Hence, migrants were comparatively darker-skinned and less refined in manner than the 'Filipinas' represent national femininity in the Manila media. When, in the mid 1990s, Filipino cinema began to portray migrant workers as national heroes, the class aspects of migration came to the forefront in the selection of mestiza actresses to play migrant roles. In 1995, the actor Helen Gamboa - married to a prominent Philippine senator and spokesmodel for a line of home appliances for the 'Filipina' housewife - took on the rather unlikely role of a migrant domestic worker. One film critic described her performance as, 'she of the porcelain complexion playing a flat-nosed, brown-skinned salt-of-the earth' (Ramos, 1995). This comment reflects the class basis for evaluations of authentic 'Filipina' identity and reveals tensions over the qualities that make a woman valuable as a citizen.

To negotiate these tensions, migrants and would-be migrants deploy 'Filipina' identity as a discursive resource. Women justify their work abroad with reference to the 'Filipina' virtues of self-sacrifice and caring for family. Since being household-centered is both a desirable Filipina trait and a motive for working abroad, migrants speak of 'sacrificing' themselves through separation 
from their loved ones in order to provide for the economic needs of their families. Aida, a would-be migrant from an indigenous community in rural Ifugao Province, explained her responsibilities as a 'Filipina' to me: I am the one who was sent to school. They sacrificed, my brothers and my parents, to pay my education. Now I am the one to earn, and to make improvements for them. That is our Filipino way.

Working overseas would reposition Aida from debtor to family patron in her household. Aida was a fresh graduate and unemployed, so sending money home, rather than remaining to do domestic chores 'for free,' was a way she imagined she could become mobile, 'improving' her position in her family and village. As one Filipina migrant in Italy said, remitting money to her family at home provides an 'emotional advantage', ensuring that the family members who benefit from the money remain obligated to her in the future (Tacoli, 1996, p. 18). This ongoing obligation, in turn, provides her with respect and social status that should entitle her to care and security in her old age. Aida, perhaps, wants the same kind of security for herself.

In Aida's language of indebtedness, we find submerged rationales directed towards acquiring social and cultural capital. Part of the lure of overseas work for rural and indigenous women - the least 'Filipina' within the nation - is that it presents a personal and familial ticket out of the skin-browning sun and into 
contacts with global 'culture', particularly as consumed by and represented through middle-class Manila society (Pertierra, 1994). To become truly 'Filipina' in the evaluation of her countrymen, a rural, indigenous woman like Aida might well decide to leave the Philippines rather than confront ethnic and class prejudice seeking work in local cities. By transforming her manners, demeanor and skin tone, work overseas would improve her ability to be recognized as 'Filipina' and thus to achieve upward class mobility in urban contexts. From the local perspective, overseas migration enacts a modern, enterprising 'Filipina' subject, resubjectivating women as globally mobile 'professionals' who should not be contained by the narrow confines of village life. In such local imaginations - often fuelled by returnees' performances migration offers both the potential to demonstrate one's value as a modern worker and provides the economic means and cultural capital necessary to enact ideals of care, self-sacrifice, and beauty underpinning traditional notions of 'Filipina' identity.

Many women see their sending locality as a place that cannot provide them with the resources to perform 'Filipina' properly. Sally, another Ifugao migrant, had just returned from her first contract and was recruiting 'girls' - including Aida for her 'auntie's' maid agency in Singapore. Sally explained the lure of overseas work for young Ifugao women: 
What's left for them here, anyway? They get married in high school, have their babies... There's no money, there's nothing here. What can they do? They are already wives, mothers but it is still kurang [lacking]. Always looking somewhere for food, for money. No nice things, no respect. So they like to go abroad. It is something new for them. There is money... but there is also new friends, new places to learn.

Sally describes a local that cannot generate the value necessary to support the performance of identities to which women aspire. In Lee and LiPuma's (2002) terms, this local is a site of 'tradition,' deficient in the value - in Sally's words, 'nice things' and 'respect' - required for Filipina femininity. In sending communities, people imagine the life of migrant workers abroad to be glamorous and economically secure. While it is generally true that their paler skin, better clothes and variety of new appliances in their homes allow people to recognize returned migrants almost immediately, people do not always see the struggles that sustain these performances. Because young women in sending villages imagine migrant success as easy, they consider migration the best route towards recognition of their own abilities and aspirations in a global frame. That migration also offers a transmutation of identity - from brown-skinned salt of the earth to napudaw (pale-skinned) 'Filipina' - makes it all the more attractive. 


\section{Being Filipina Abroad}

Outside the Philippines, however, 'Filipina' means something quite different. The perceptions of migrant receiving nations and elites have refigured 'the Filipina' into the 'Filipina-as-maid,' a generalized unskilled body (Parreñas, 2001; Pratt, 1997 and 1998). ${ }^{10}$ In the Philippines, there is a growing perception is that 'Filipina' identity has been debased and the nation embarrassed by the association of 'Filipina' with domestic work (Rafael, 1997). Professional and academic women have published personal accounts of perceived discrimination against them as 'Filipinas' and therefore servants, despite what their visa, passport, class of travel or clothing might indicate. This global version of 'Filipina' justifies disparaging the skills and abilities of labor migrants while encouraging their differentiation from professional Filipino emigrants, thus frustrating their hopes of class mobility. Whilst overseas, many migrant domestic workers find themselves devalued as an embodied extension of the economic space of their sending village - the very space of limits they are attempting to transcend. ${ }^{11}$

The limits of contract domestic work are often more constraining than women in sending villages might imagine. Domestics live and work in private households in conditions that often restrict their mobility and social contacts (Mills, 2003). Most tend to socialize - when permitted - with other migrants from their sending 
locality in kin and co-religious groups (Constable, 1997, 2003; Law, 2001). Even though they make take successive contracts, migrants' communication and remittance practices maintain a sense of social immediacy with sending localities. Migrants use cell phones, remittance agencies and banks to channel money home, while they interact with kin and friends through text messages, letters, phone calls, tapes, e-mail and sometimes video. Migrants also ship home 'balikbayan boxes', large boxes containing household goods and clothes (Rafael, 1997; Szanton Blanc, 1996). This sense of immediacy is also produced through and consociality with migrant village-mates. Migrants organize their consociality around interacting with churches, banks, remittance and employment agents, meeting kin and friends as they send money, select consumer goods for shipping, and find new employment on days off. These activities also allow for the exchange of news items received from the Philippines. Migrants often compare notes - and photographs and text messages - with friends from the same sending village to evaluate their transnational relationships. At home, people make similar comparisons, evaluating the amounts received, the content of communication, and the redistributions of gifts arriving in the balikbayan boxes. Dependents and village-mates assess migrants for their generosity, responsiveness, and thoughtfulness, based on the text messages, phone calls, and goods they send. Migrants, in turn, examine expressions of care made by their transnational dependents against the evidence 
of thrift and diligence in managing the money they remit. Everyone compares the success of sending households in pursuing the education, house-building, small enterprise and farming funded by migrants' wages. More often than not, progress at home does not match up with the expectations of the migrant overseas.

Being 'Filipina' as a migrant thus involves meeting obligations to those at home, internalizing external views of a colonized, ethnicised self and navigating the stereotypes produced by both a national discourse of femininity and those created by previous cohorts of Filipinos abroad. Consociality abroad, particularly shared with other Filipinos and host nationals, plays a major part in shaping individual experiences of migration. Social networks abroad can enable further economic mobility and eventually help migrants to achieve 'permanent' status. Consociality itself constitutes migrant subjectivities through recognition and inflects expectations for returns home with memories based on the 'good life' as lived by Filipino consociates elsewhere.

In research undertaken in Canada, domestic worker respondents felt excluded from important forms of consociality because of their 'Filipina' identity. The following quotes exemplify two distinct modes of their resubjectivation as 'Filipina' subjects. 
Luz, 40s, was working in Canada as a 'nanny-caregiver'Because I don't want to be just a nanny anymore, I went for evaluation and my degree wasn't even recognized. And I became realistic about it. Even though we have a good education, it doesn't matter to them. Because we're Filipino we are only a domestic helper... And I became realistic about it. I'm not shy to become a domestic worker. That I'm a Filipino woman, I'm not ashamed to anybody. Everybody is the same. (B)eing a Filipino... they look at us like we're small. Even though we have a good education, it doesn't matter to them. Because we're Filipino we are only a domestic helper. They only can control us because they have the money and power, of course, here in Canada. Sasha, 20s, was originally a caregiver, and now works with a Canadian NGO Actually, between the Filipino community...- people who came directly as landed immigrants $^{12}$ - they look down on the domestic workers. There's a very strong separation. 'So you're only a nanny; we don't really communicate with you or we don't really deal with you'. And so the Filipinas have a tendency to stick within their domestic workers group.

These quotes make clear how migrants trying to perform 'Filipina' identities experience deeply embedded contradictions. On the one hand, being 'Filipina' equates to being 'only' a domestic worker. Thus, Luz feels broader Canadian society devalues her because 'Filipinas' are thought to be incapable of other 
work. On the other hand, other Filipinos exclude domestic workers from their social networks, as Sasha describes, because they assume that they must come from lower-class backgrounds in the Philippines. In this situation, domestic worker migrants find they are at once 'too Filipina' to move beyond domestic work and into the Canadian labor market and not 'Filipina enough' - meaning cultivated, well-spoken, pale-skinned, professional or upper class - to enjoy the relationships with a longstanding community of 'professional' Filipino migrants in Canada.

Some Filipino Canadians reject 'Filipina' identity altogether, instead identifying themselves as 'Filipino women' instead. ${ }^{13}$ In group interviews with Filipino Canadian women who were not domestic worker migrants, almost all of interviewees described experiences of identification as 'Filipina-as-maid.' They traded tips on performing 'professional' identities that distinguished them from domestic workers, including selecting certain types of haircuts, glasses, handbags, and other accessories; considering the cuts, colors, and quality of clothes; and adjusting their demeanor, manners and tone of voice. Their advice reveals both practices of evaluation attached to performances of class background and their own imaginations of transnational forms of status. For them, 'Filipina' identity now serves as the Other against which emigrants define globally-mobile selves who are 'Filipino women' with Canadian passports. 
Domestic worker migrants find these forms of evaluation, recognition, and imagination exclude them from social networks that would help them to find other kinds of work. In Canada, they discover that 'Filipina' names a lesscapable and valued sort of 'Filipino woman' as they struggle to gain recognition as 'professional' caregivers (Pratt, 1998).

\section{Circulation, Identities and Ambivalence}

Work overseas does open up new spaces of female freedom in migrants' Philippine sending neighborhoods and households. Earning abroad can provide an accepted way of buying out household obligations attached to women based on their gender, age, and kin status. Families often pressure youngest or eldest daughters to remain unmarried and live with their parents, doing household and farm work to care for them in their old age. By remitting money, a daughter expected to remain the unmarried caretaker can purchase care, usually by supporting another kin member who then cares for her parents. Discharging this obligation gains the migrant familial approval for her marriage or relocation (Pertierra, 1994). Sending money can likewise free migrant women from obligations to consult husbands and parents when making decisions about their own lives and work (Tacoli, 1996). Moreover, migrants can decide to retain some of their earnings for their own independent investments in education, 
further migration and small enterprises (Gibson et al., 2001). While dependent households can resent these diversions, claiming a right to the migrant's full salary because of her gendered maternal or filial duty, such claims are negotiable. Migrants thus use their experiences of migration and the values it generates to become other kinds of subjects - business people, investors, politicians, and 'leading citizens.'

Filipinos recognize the transformations engendered through migration by ascribing a new identity - balikbayan - to returned migrants. This word combines the Tagalog for return, balik, with that for town, bayan - a term later extended to mean nation (Szanton Blanc, 1996, p. 178). Like 'Filipina', balikbayan identity has a genealogy steeped in colonial relations. The term initially appeared in the post-war era, naming Filipino emigrants visiting the homeland from the United States (Rafael, 1997; Szanton Blanc, 1996). Filipinos experienced balikbayans from America as snobbish and superior, frequently disparaging the nation they had left behind. The boxes of gifts they brought home offered locals a taste of the good life in America but also served to demonstrate the inadequacy of the Philippines. Though contract workers also began to bring boxes of gifts home to kin in order to gain their respect and recognition, the two categories of returnees remained distinct (Rafael, 1997). By the late 1980s, however, there was a transition in the meaning of balikbayan and 
Filipinos began to apply the term to returning migrant workers (Szanton Blanc, 1996). In 1989, the Philippine government introduced special duty-free status for boxes of gifts (as long as the items were 'used goods') as a combined strategy to encourage 'return tourism' from Filipino-American emigrants and allow contract workers to bring additional value home to their households (Szanton Blanc, 1996). By effectively including migrant workers within the 'visitor' category of balikbayan, this government policy reflected the conflation of identities that had already occurred. One of my Ifugao respondents explained: 'Because, here, we have no migrants in America, these OCWs (overseas contract workers), they are now our balikbayans here'.

Sending community respondents expressed pride in 'our balikbayans.' A series of performative practices that might be described as a 'balikbayan style' enabled local people to recognize returned contract workers and visiting American emigrants alike. My interviewees identified these as fairer skin, a particular style of movement and presentation, distinctively imported clothes, and the use of make-up. For them, these forms of balikbayan cultural capital indicated the inherent value of their locality, reflecting the quality of local abilities and resources and the economic diversity and cultural sophistication of their community. 
Economic positioning was another distinctive part of balikbayan identity and returned migrants in the rural, agricultural communities of my research did not return to farming. Some respondents simply wanted to 'sit down', feeling that they had done 'enough' hard manual labor while abroad. Others explained that their reluctance to return to on-farm work came from an expectation that their community would evaluate them as 'failed' in their plans. Instead, returnees cultivated straightened hair, polished nails, make-up, shoulder-strap purses, and imported clothes, much like the 'professional' Filipino-Canadians. In Ifugao, their neighbors described such returned female migrants as 'very Filipina now' and considered them to be self-made women.

As with the tensions around 'Filipina' identity discussed above, there are similar practices of evaluation and constraint attached to performances of balikbayan. Recognition as a 'true' balikbayan requires economic success on return home. Such success is associated with evaluations of selfishness, self-sufficiency and a set of class differences that emerge between returned migrants and their sending communities and families. While returning migrants are happy to be close to loved ones again, they are usually apprehensive about the possibilities for economic security and new social obligations attendant in balikbayan identity. They often feel ambivalent about returning home (Constable, 1999). Behind the expectations and ambivalence lie multiple imaginations and recognitions. 
Respondents in sending communities resisted the idea that work overseas did not necessarily provide financial security for balikbayan women. Instead, they imagined that balikbayans who did not meet economic expectations were simply being stingy with their savings. Returnees, however, found themselves thrust into new public roles as patrons. Balikbayan respondents fielded constant requests to donate to the church, sponsor fiesta activities, host visitors, and make loans to distant kin who were unlikely to repay. While some returnees were able to take on patronage roles, others found these expectations constraining. For a few, recurrent demands for money arose from within the very intimate relationships they had missed most while overseas. They experienced this as exploitation and developed strong feelings of resentment and alienation.

The forms of evaluation attached to balikbayan identity also marked new practices of economic exclusion. One of my respondents, Tala, had invested her savings from work overseas to become a local distributor of Tupperware. Her in-laws, cousins, and neighbors took the containers from her on credit and were then apparently unable to pay their debts. After two humiliating months of trying to collect these bad debts, Tala's business failed. When I asked her neighbors about this, they argued that, since Tala was 'already rich from abroad', she did not need their money. Tupperware, for her, they claimed, was 'just a sideline'. Tala, however, told me that she had lost her savings in the venture. 
She was now considering taking a loan so she could apply for another contract in Singapore, much as she disliked the idea of leaving her children again. Tala thought that her other option, to run a small sari-sari (single mixed business) store from her house might be similarly doomed: 'If you do not give credit, they will not buy anything, but if I give credit, they say 'never mind, she's OCW [an overseas contract worker] already', and then it is only credits and never money. People are jealous here; they don't want to know how hard it is, abroad'. Tala's comments encapsulate the anxieties of many returned women; if they are unable to balance local expectations against personal success, they will fail as both balikbayan and 'Filipina.'

Tala's experience exemplifies the new forms of recognition and imagination that comprise the culture of circulation surrounding economic migrants. In the Philippines, returnees find very limited possibilities for productive investment because their personal savings are usually not of the magnitude required for medium-to-large-scale entrepreneurial activities. Rather, like Tala, returned overseas workers frequently open small sari-sari stores, selling basic grocery items and sweets, usually on credit. Another popular option is to invest in local transport networks, putting capital into small passenger vans, taxis or motorcycles with sidecars. ${ }^{14}$ Neither investment offers the same possibility for generating income for the household, nor the same social status as work abroad. 
The evaluation of neighbors and family as to the 'success' of the balikbayan, the constraints of community expectations on returned women's actions, and exclusion from local social networks on the basis of women's new balikbayan identity all serve to resubjectivate returned women. Being unable to live up to the expectations and become a 'true' balikbayan, rather than a failed one disparaged as a 'one day millionaire' (see Constable, 1999) - is a common reason for women to take on subsequent contracts.

\section{Conclusion: Circulation and Value}

This essay has shown how the 'culture of circulation' attached to women's migration from the Philippines emerges from movement between two poles of identity- the yin of the 'Filipina' and the yang of the balikbayan. Mediating between these two poles are flows of cash and other forms of value, expressed through the cultural concepts of indebtedness and enterprise attached to both identities. Circulation - not just of money but also of cultural and social capital between the poles - creates new female subject positions and enables new feminine subjectivities to emerge. The resulting 'culture of circulation' changes the sociality and reproducibility of household economies and the forms of agency attached to gendered identities. As a result, the forms of value generated within the translocal cultural fields of migration encourage continual movements of women to and from sites overseas. In this process, identities do important 
work. As Jonathan Friedman (1994, p. 171) observes, under globalization, 'the construction of identity space is the dynamic operator linking economic and cultural processes. It is the source of desire and the specific motivations that generate representational schemes.' In other words, the new kinds of subject positions created within the particular forms of economic organization characteristic of globalization also do the work of making culture. However, such culture can no longer be located solely within the familiar, bounded localities of traditional ethnographic fieldwork. Instead, experiences of mobility and migration transform previously place-bound subject positions into transnational identities, engaging them in new cultural processes and representational schemes. By unpacking two of the identities produced through Filipino migration and theorizing them within a 'culture of circulation', I have demonstrated how the particular economic relations of globalization are mutually constitutive of specific forms of meaning and identity. Through this lens, we see migrant women as more than 'victims' caught up within global processes; they are revealed as innovators, actively renegotiating identities and relations. 


\section{Acknowledgements}

Thanks to respondents in the Philippines and Canada and to friends at the

Philippine Women Center, Vancouver, who hosted a co-operative research

project from 1999 to 2001. At the Australian National University, I am grateful to my colleagues, Michelle Carnegie, Benjamin Smith, and Kathryn Robinson, for helpful comments on earlier drafts and to Sandra Davenport, Department of Human Geography, for assistance in editing and formatting. 


\section{References}

Anderson, Bridget. 'Different Roots in Common Ground: Transnationalism and Migrant Domestic Work in London', Journal of Ethnic and Migration Studies 27, no. 4 (2001), pp. 673-683.

Aguilar, Filomeno. 'Ritual Passage and the Reconstruction of Selfhood in International Labor Migration', Sojourn 14, no. 1 (1999), pp. 109-39.

Banzon-Bautista, Cynthia. 'The Saudi Connection: Agrarian Change in a Pampangan Village, 1977-1984', in Agrarian Transformations: Local Processes and the State in Southeast Asia, eds Gillian Hart, Andrew Turton, and Benjamin White, (Berkeley: University of California Press, 1989), pp. 144-58.

Barber, Pauline. 'Agency in Philippine Women's Labor Migration and Provisional Diaspora', Women's Studies International Forum 23, no. 4 (2000), pp. 399-411.

Boyle, Paul. 'Population Geography: Transnational Women on the Move', Progress in Human Geography 26, no. 4 (2002), pp. 531-43. 
Constable, Nicole. Maid to Order in Hong Kong: Stories of Filipina Workers (Ithaca: Cornell University Press, 1997).

'At Home but Not at Home: Filipina Narratives of Ambivalent Returns', Cultural Anthropology 14, no. 2 (1999), pp. 203-28.

'A Transnational Perspective on Divorce and Marriage: Filipina Wives and Workers', Identities: Global Studies in Culture and Power 10, no. 2 (2003), pp. $163-80$.

Gibson, Katherine, Law, Lisa, and Deirdre McKay. 'Beyond Heroes and Victims: Filipina Contract Migrants, Economic Activism and Class Transformation', International Feminist Journal of Politics 3, no. 3 (2001), pp. $365-86$.

Friedman, Jonathan. Cultural Identity and Global Process (London, Sage Publications, 1994).

Hugo, Graeme. 'Women's International Labor Migration' in Women in Indonesia: Gender, Equity and Development, eds Kathryn Robinson and Sharon Bessell, (Singapore: Institute of Southeast Asian Studies, 2002), pp. 158-78. 
Lan, Pei-Chia. 'Maid or Madam? Filipina Migrant Workers and the Continuity of Domestic Labor', Gender \& Society 17, no. 2 (2003), pp. 187-208.

Law, Lisa. 'Home Cooking: Filipino Women and Geographies of the Senses in Hong Kong', Ecumene 8, no. 3 (2001), pp. 264-83.

Lee, Benjamin and Edward LiPuma. 'Cultures of Circulation: The Imaginations of Modernity' Public Culture 14, no. 1 (2002), pp. 191-213.

Mills, Mary Beth. 'Gender and Inequality in the Global Labor Force', Annual Review of Anthropology 32 (2003), pp. 41-62.

Momsen, Janet. 'Maids on the Move', in Gender, Migration and Domestic Service, ed Janet Momsen (London and New York: Routledge, 1999), pp. 1-21.

Nagasaka, Itaru. 'Kinship Networks and Child Fostering in Labor Migration from Ilocos, Philippines, to Italy', Asian and Pacific Migration Journal 7, no. 1 (1998), pp. 67-92. 
Parreñas, Rachel. Servants of Globalization: Women, Migration and Domestic Work (Stanford: Stanford University Press, 2001).

—Children of Global Migration: Transnational Families and Gendered Woes. (Stanford: Stanford University Press, 2005).

Pertierra, Raul. 'Lured Abroad: The Case of Ilocano Overseas Workers', Sojourn 9, no. 1 (1994), pp. 54-80.

Pertierra, Raul ed, with Minda Cabilao, Marna Escobar and Alicia Pinggol, Remittances and Returnees: The Cultural Economy of Migration in Ilocos, (Quezon City: New Day Publishers, 1992).

Philippine Women Center of British Columbia. 'Housing Needs Assessment of Filipina Domestic Workers'. A Study conducted by the Philippine Women Centre, Vancouver, B.C., 1996.

Pratt, Geraldine. 'Stereotypes and Ambivalence: The Construction of Domestic Workers in Vancouver, B.C.', Gender, Place and Culture 4, no. 2 (1997), pp. $159-77$. 
'From Registered Nurse to Registered Nanny: Discursive Geographies of

Filipina Domestic Workers in Vancouver, B.C.', Economic Geography 75, no. 3 (1999), pp. 215-36.

Pratt, Geraldine with the Philippine Women Center, Vancouver. 'Inscribing Domestic Work on Filipina Bodies', in Places through the Body, eds Heidi Nast and Steven Pile (London and New York: Routledge, 1998), pp. 283-304.

Ramos, G. 'The Other Flor Contemplacion', Today, C22, May 31, 1995.

Puri, Shivana and Tineke Ritzema. 'Migrant Worker Remittances, MicroFinance and the Informal Economy: Prospects and Issues', Working Paper No 21, International Labor Office, Geneva, 1999.

Rafael, Vincente. 'Your Grief is Our Gossip: Overseas Filipinos and Other Spectral Presences', Public Culture 9, no. 2 (1997), pp. 267-91.

Rodriguez, Edgard. 'International Migration and Income Distribution in the Philippines', Economic Development and Cultural Change 46, no. 2 (1998), pp. 329-50. 
Szanton Blanc, Cristina. 'Balikbayan: A Filipino Extension of the National Imaginary and of State Boundaries', Philippine Sociological Review 44, no. 1-4 (1996), pp. 178-93.

Tacoli, Cecilia. 'Migrating "For the Sake of the Family"? Gender, Life-Course and Intra-Household Relations among Filipino Migrants in Rome', Philippine Sociological Review 44, no. 1-4 (1996), pp. 12-32.

Tung, Charlene. 'The Cost of Caring: The Social Reproductive Labor of Filipina Live-In Home Health Caregivers', Frontiers 21, no. 1-2 (2000), pp. 61-82.

Tyner, James and Daniel Donaldson. 'The Geography of Philippine International Labor Migration Fields', Asia Pacific Viewpoint 40, no. 3 (1999), pp. 217-34.

Westwood, Sallie and Annie Phizacklea. Transnationalism and the Politics of Belonging (London: Routledge, 2000).

\footnotetext{
${ }^{1}$ In this village, as elsewhere in the Philippines, female migration links specific sending places with receiving neighborhoods overseas through highly personalized relations, often of kinship (see Pertierra et al., 1992). During my
} 
fieldwork, I met women who had spent up to 25 years working outside the Philippines, putting successive generations of their families through school and investing in land, housing, and health care, only to see their well-educated daughters join them in Hong Kong, working for another generation of the same family of employers.

${ }^{2}$ Palmer-Beltran (1991, cited in Lan, 2003, note 18) reports on a survey of 3099 prospective overseas workers conducted in 1990-1991 in a predeparture orientation seminar. 61 percent of respondents were aged 21-30, 28 per cent were 31-40. 43 per cent were high school graduates, 36 per cent had a college degree or some college education, and 11 per cent had completed a vocational course. Over 80 per cent of the respondents reported they were single, 18 per cent were married.

${ }^{3}$ Tung (2000) reports 75 per cent remitted from a study of Filipina elder-care providers in Los Angeles, while Chin (1997), cited in Momsen (1999, p. 9) reports 50 per cent remitted for Filipinas in Malaysia, and PWC (1996) reports 30 per cent of salary remitted for Filipinas working under the Live-In Caregiver Program in Vancouver, Canada.

${ }^{4}$ See Anderson (2001); Constable (1997 and 2003); Parreñas (2001); Pratt (1997, 1998, and 1999) and Tacoli (1996).

${ }^{5}$ See Banzon-Bautista (1989); Nagasaka (1998); Pertierra (1994), and Parreñas, (2005). 
${ }^{6}$ See Barber (2000) and Constable (1999).

${ }^{7}$ I have drawn these identities from the literature on Filipina migration and my own observations. As in any ethnographic work that reflects a lived, real world, many of the identifications overlap between authors and studies, thus I have chosen not to attribute the exploration of specific identities to particular authors here.

${ }^{8}$ Filipino terms appear in italics and I define them in brackets on their first appearance within the text. Single quotes indicate terms used by respondents speaking Filipino English.

${ }^{9}$ This usually occurs through offspring with nursing qualifications who then reunite the family, or through special migration streams such as Canada's LiveIn Caregiver Program (for details of the latter, see Pratt, 1997, 1998, and 1999). 10 'Filipina' identity is also associated with sex work - japayuki being the term identifying Japan-based 'entertainers'- but debates in the Philippine media have generally focused on the conflation of 'Filipina' with 'maid.'

${ }^{11}$ In response, several of my indigenous Ifugao respondents decided to conceal their ethnic identity from fellow Filipinos while abroad.

${ }^{12}$ Filipinos who migrate to Canada as skilled professionals receive rights of permanent residency (landed status) on arrival while those who arrive under the Live-In Caregiver Program must do 24 months of domestic work (being a 
'nanny') in order to qualify for permanent resident status (see Pratt, 1997, 1998 and 1999.)

${ }^{13}$ This observation comes from comments made during interviews at the Philippine Women Center of British Columbia, Vancouver, 1999.

${ }^{14}$ The growth in the number of public transport vehicles - many illicit - has led the Philippine government to make public pleas to migrants and their families to invest elsewhere. 